\title{
A New Recording Snowgage, Buried-Type
}

\author{
by \\ M. Tamura and N. Tsuda \\ Meteorological Research Institute, Tokyo \\ (Received October 8, 1958)
}

\begin{abstract}
A buried-type snowgage is introduced which measures and records the amount of snow-cover in the natural state as snow lies on the ground. A pit is dug with $4 \mathrm{~m}$ diameter and with $30 \mathrm{~cm}$ depth and a loop-type strain-meter is installed on a foundation at its center. Foundations are also made along the circumference, and beams are put circularly and radially between these foundations and from them to the strain-meter at the center. The beams support plates on them, on which soil coverage is spread until its surface is level with the surrounding ground. The strain at the center, which is equal to $1 / 3$ of the weight of snow-cover on the circle, is magnified and transferred with links to a recorder $4 \mathrm{~m}$ apart from the center. From the fact that the result of the test measurement made at Hokkaido University campus agrees very well with that of the simultaneous observations with a snow-sampler, the gage seems quite satisfactory for practical use for the measurement of snow-cover.
\end{abstract}

\section{Introduction}

For the intake of snowgage, the shape of orifice similar to that for raingages has been adopted hitherto. The snowflakes, however, are more sensitive to wind than raindrops, and an accurate measurement of snow amount with the pickups of the conventional shape is impossible even though they may be equipped with windshields, and further the icing or the deposit of snow at the orifice edge presents another problem. The gage introduced here aims to measure and record the snowamount with greater accuracy uninfluenced by wind, by means of weighing the snow cover in the natural state as it lies on the ground surface. The model manufactured for trial performed a satisfactory measurement in its test.

\section{Preliminary experiment}

Prior to the trial layout, fundamental experiments were carried out on the problems: (1) How would the snow layer be distorted when it 'sinks over the gage? and (2) How would the load on the gage vary when the layer is distorted?

As a model representing snow cover, gelatine solied-moulded from $3 \%$ gelatine 
solution-was used, for which the internal strain was observed or the variation of pressure at the bottom was measured.

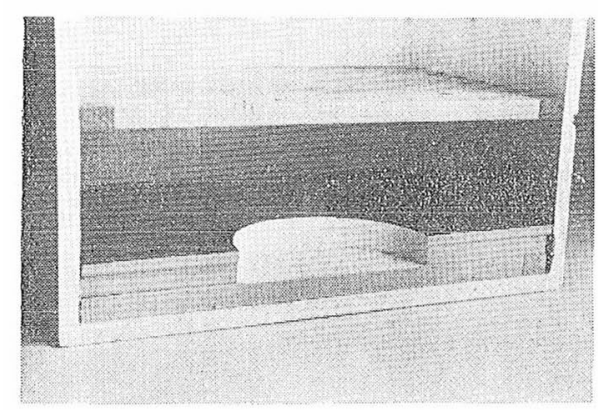

Fig. 1. The casting-box for gelatine, the side-plate being disconnected.

For investigating the problem (1) three blocks of gelatine with $3 \mathrm{~cm}, 6 \mathrm{~cm}$, and $12 \mathrm{~cm}$ thicknesses, respectively, were moulded by a casting box with $60 \mathrm{~cm} \times 50 \mathrm{~cm}$ plan (Fig. 1). A semi-circular hollow with $10 \mathrm{~cm} \mathrm{ra-}$ dius is cut at the bottom plate of the box as is seen in the picture, and a semi-circular patch plate which is exactly the same size as the hollow, and which represents the present snowgage, is fitted into it. After the gelatine solidifies, one of the side-plate of the box is removed, the exposed side of the gelatine block is smeared with Indian ink, crosslines of $5 \mathrm{~mm}$ interval both horizontally and vertically are drawn on it, with a razorblade and then the side-view is photographed. Then the inlaid plate at the bottom is taken away, i. e. a hollow of $10 \mathrm{~cm}$ radius is cut out in the bottom, that part just on the hollow which represents the snow on the snowgage sinks, and the side-view is double-exposured on the same photo-plate. The double lines on the developed plate. (Fig. 2 (a) and (b)) express the distortion due to the ex-

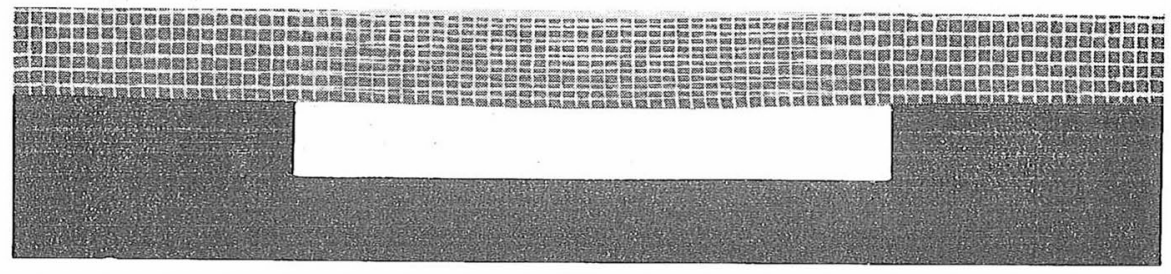

(a)

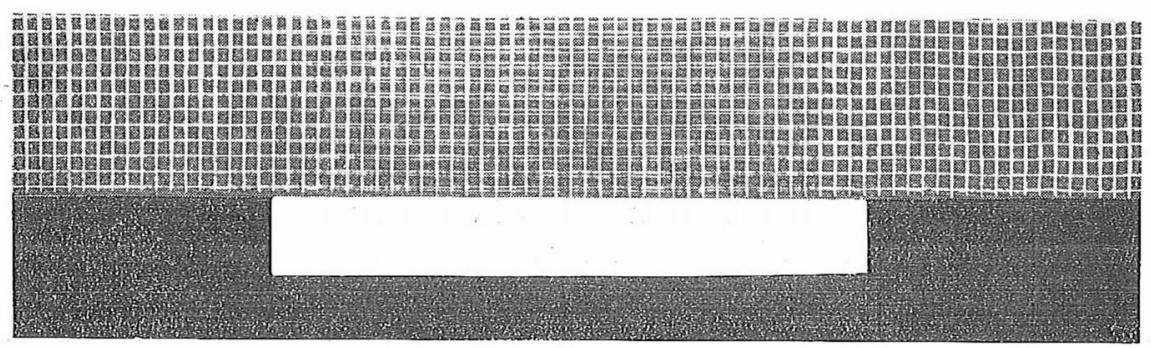

(b)

Fig. 2. The side-view of gelatine-block with cross-lines.

(a) Thickness $3 \mathrm{~cm}, \rho=1.02$

(b) Thickness $6 \mathrm{~cm}, \rho=1.03$

istence of the hollow, and it is clear from it that the effect of the hollow extends to the upper layers spreading horizontally in a funnel shape. Serial experiments show that the thicker the layer, the smaller the amount of distortion that results from hollows of the same diameter. 
For the other problem (2), a basin of $50 \mathrm{~cm} \times 50 \mathrm{~cm}$ plan $\times 30 \mathrm{~cm}$ depth, under which a balance is coupled through a hole at the bottom, is used for the investigation of the variation of load with distorted layer. The bottom hole is of an octaganal shape with the opposite sides $15 \mathrm{~cm}$ apart, the scale being $1 / 25$ of the original. Eight isosceles triangular flaps are hinged at each side, the apices concentrating at the center of the hole. A thin vinyl sheet covers the whole bottom, onto which liquid-gelatine is poured, and the load at the center is weighed with a balance (Fig. 3 (a) and (b)). While the gelatine is in a liquid form, the load is measured to be

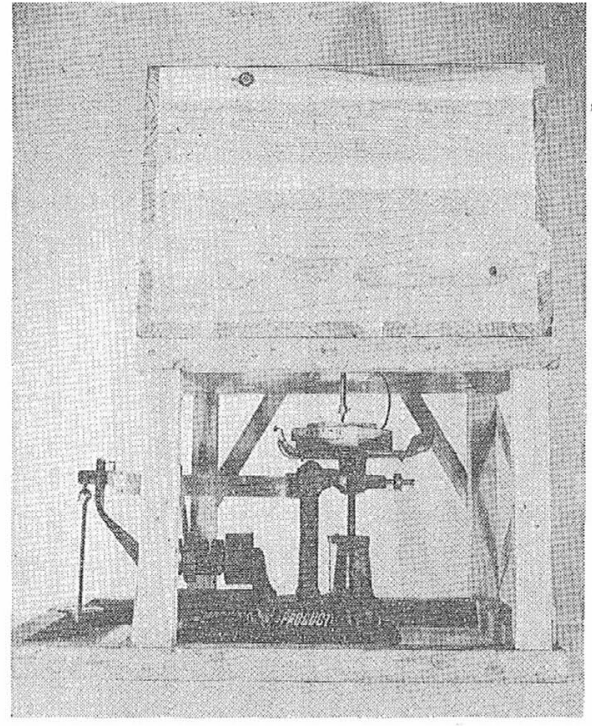

(a)

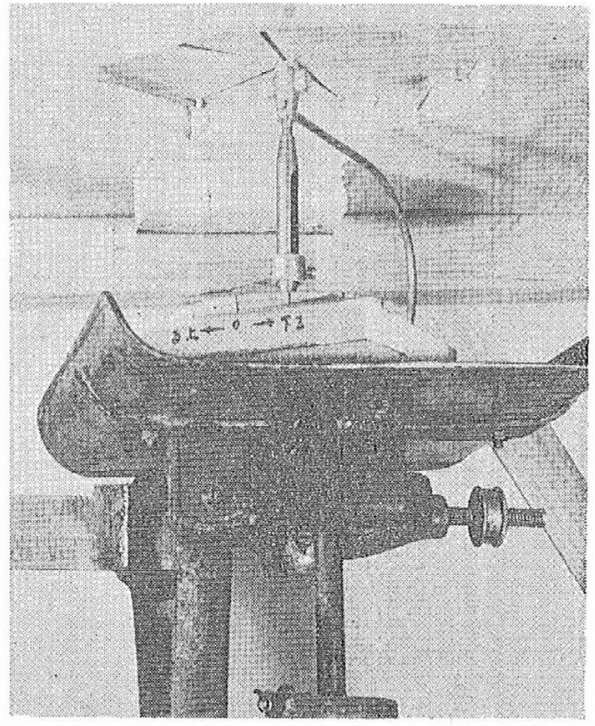

(b)

Fig. 3. The model experiment with a balance.

(a) The side-view for the whole system.

(b) The close-up showing the octagonal hole.

just $1 / 3$ of the weight of the whole volume on the octagon as theoretically deduced; but after the gelatine solidifies, some different value is obtained at the balance. The value varies with the thickness of the gelatine above the octagon, the diameter, the depth of the sink at the balance pick-up, the hardness of gelatine, etc. Fig. 4 gives the relation of the load variation to the sink depth or distortion amount for different gelatine hardness, with the present size model. The results of this experiment mean that a similar type snowgage gives inaccurate indication in accordance with the snow character, the snow depth, etc., though the error would not be so much as in the case of gelatine since snow has a plasticity differing from gelatine. For accurate measurement, it is required to make the distortion amount as small as possible, and then the side distance need not be always so great. 


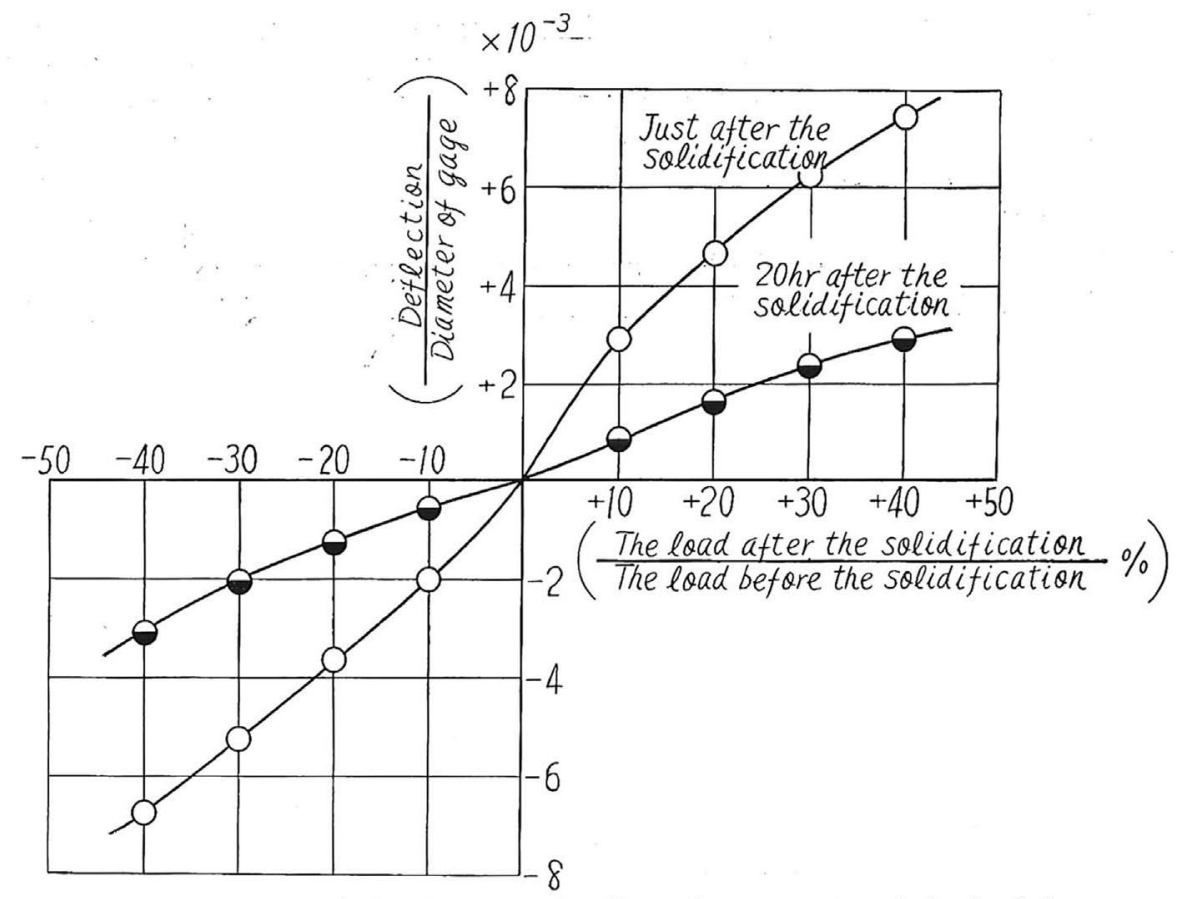

Fig. 4. The relation between the distortion amount and the load for the snowgage model using gelatine for snow.

\section{Construction of snowgage}

Soil of $4 \mathrm{~m}$ in diameter and $30 \mathrm{~cm}$ in depth is cleared away from plain land. For foundation, a concrete block on pine log piles is laid at the center and at sixteen equal distance points along the circumference of the pit. A strain-meter with an ellipse loop of $\mathrm{Ni}$-Cr-Mo-steel (Fig. 5) is put on the central foundation. Cypress timbers, $7.5 \mathrm{~cm}$ in breadth and $15 \mathrm{~cm}$ in height, are bridged across connecting these seventeen foundations, upon which cypress plates

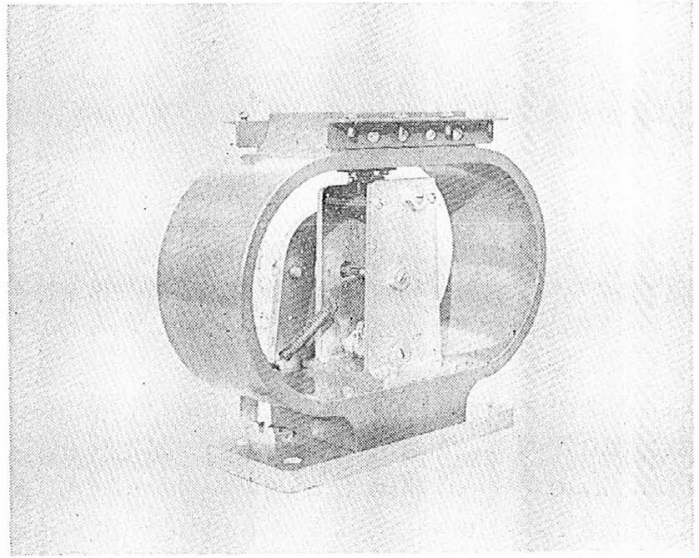

Fig. 5. The strain-meter. of $2.4 \mathrm{~cm}$ thickness are arranged in a floor, the whole wood weighing some 1.3 ton. A large vinyl sheet is laid on the floor, soil is spread on it $5 \sim 6 \mathrm{~cm}$ thick, and then the surface is made level with the surrounding land condition (Figs. 6 and 7). The displacement of the strain-meter is magnified. mechanically through a sector gear transformed into the rotation of steel-pipe which extends to a point outside the pit and $4 \mathrm{~m}$ apart from the center, and then is led to the recorder-pen (Fig. 8) which is hung at a height of $1 \mathrm{~m}$ above the ground level at the point. For the load of 3 tons 


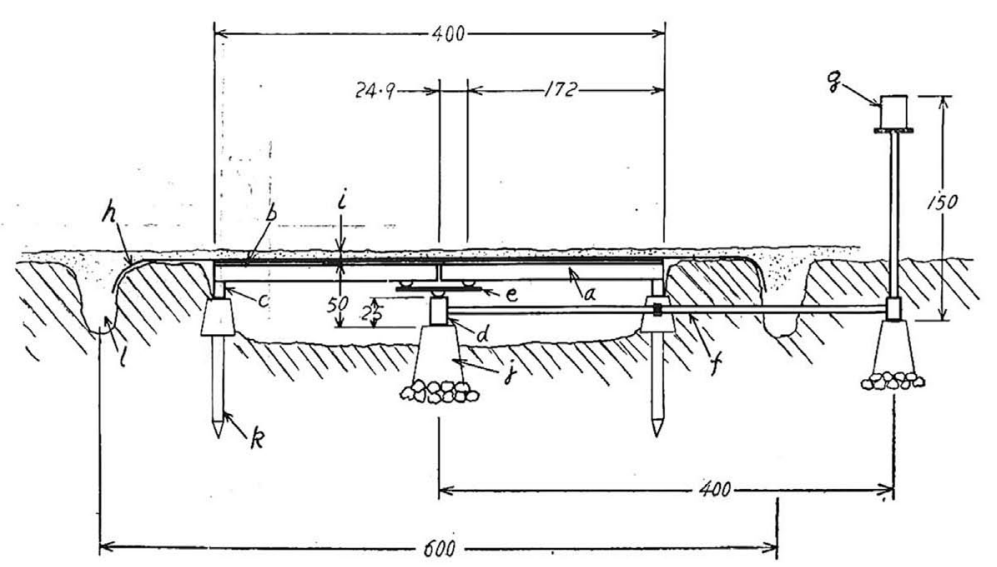

a) Spoke $(7.5 \times 15)$

b) Cypress plate $(t=2.4)$

g) Recorder

c) Cypress timber $(7.5 \times 15)$

h) Vinyl sheet

d) Strain-meter

e) Steel-plate

f) Protector-Pipe $\left(1^{1 /} / 2^{\prime \prime}\right)$

i) Soil $(t=5 \sim 6)$

j) Concrete-block

k) Pine log pile

Fig. 6. Skeleton view of the snowgage (Unit for length is sentimeter if not indicated specially).

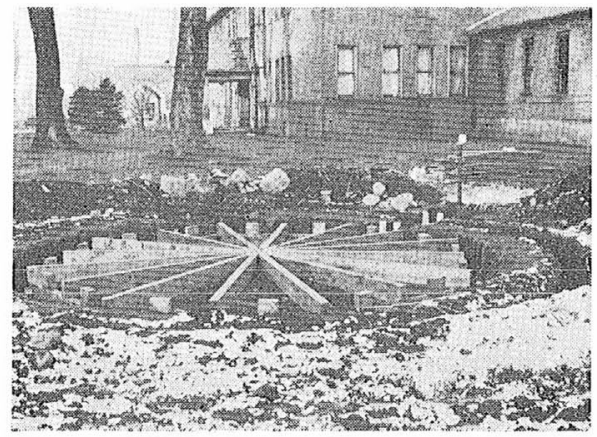

(a)

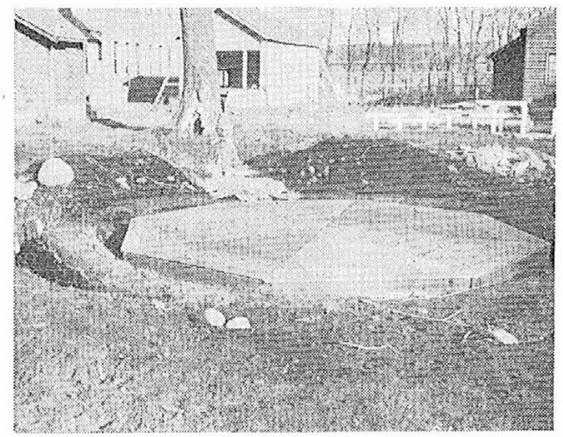

(b)

Fig. 7. The whole set-up of the snowgage made for trial.'

(a) - Showing the inner beams.

(b) The outlook before the surface soil is spread.

at the center, the loop deflects $1,356 \mathrm{~mm}$ and the pen records $81 \mathrm{~mm}$ variation, the proportional constant being $0.0357 \mathrm{ton} / \mathrm{mm}$ for the recorder reading, and then the magnification throughout the whole system reaches some 60 times.

Fig. 9 shows the details of the pick-up mechanism, that is, the load from the isosceles triangles is transmitted to the steel disk below through halved pipe bearings not at the apices but at the distance $r=24.9 \mathrm{~cm}$ from the apices, and then the semispherical steel bearing below the disk delivers the concentrated load to the strain-meter. The discrepancy at the apices results in the load for strain-meter 


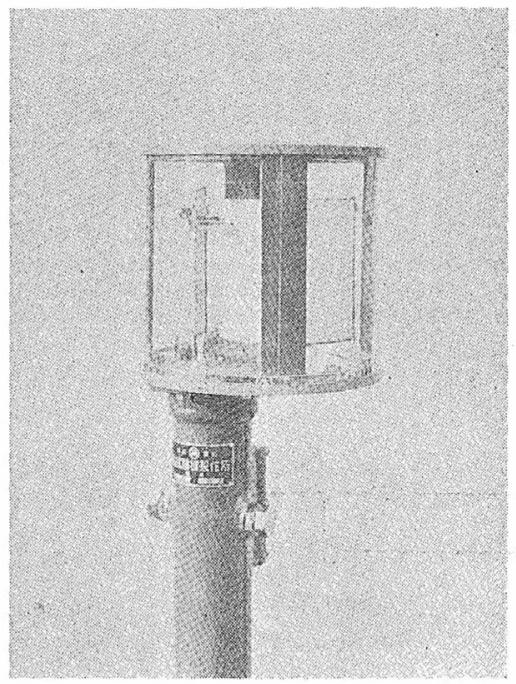

Fig. 8. The recorder.

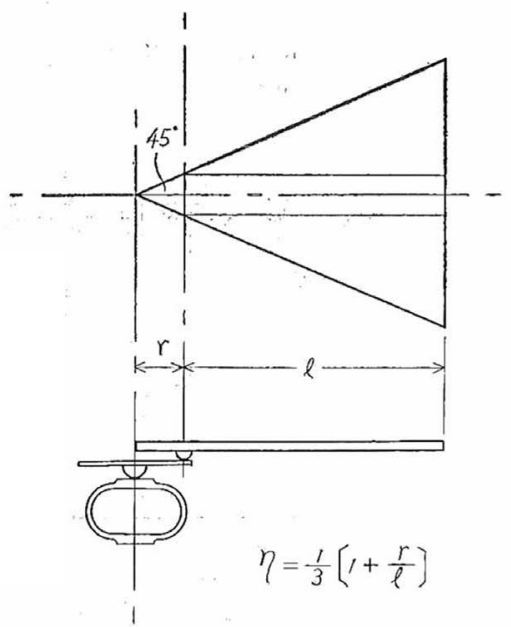

Fig. 9. The details of the pick-up mechanism.

being not $1 / 3$ of the total weight of snow accumulated there, but $1 / 2.62$, as it is reduced by $\eta=\frac{1}{3}\left(1+\frac{r}{l}\right)=\frac{1}{2.62}$, where $l=172 \mathrm{~cm}$ (Side length of octagon $m=163.2 \mathrm{~cm}$ : total area of octagonal plane $A=12.85 \mathrm{~m}^{2}$ ). The present snowgage is capable of measuring a snow cover up to $2 \mathrm{~m}$ depth for snow with the average density of 0.3 .

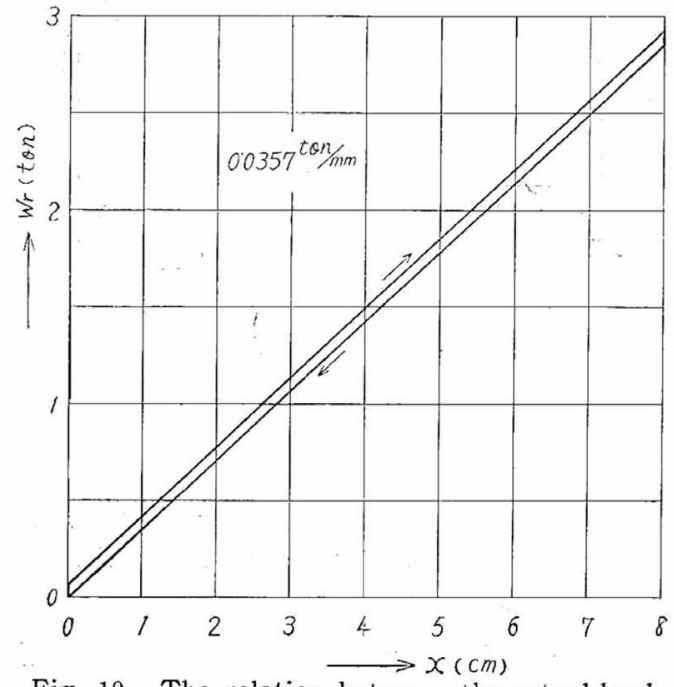

Fig. 10. The relation between the actual load at the pick-up and the recorder reading, for the whole set-up of the present snow gage.
Table 1. The relation between the load and the recorder reading, for the strain-meter alone.

\begin{tabular}{c|c|c}
\hline \multirow{2}{*}{ W (kg) } & \multicolumn{2}{|c}{$\delta(1 / 100 \mathrm{~mm})$} \\
\cline { 2 - 3 } & Go & Return \\
\hline 0 & 0 & 0 \\
500 & 22.2 & 22.2 \\
1000 & 45.5 & 45.5 \\
1500 & 68.3 & 68.4 \\
2000 & 90.2 & 90.3 \\
2500 & 112.6 & 112.7 \\
3000 & 135.6 & - \\
\hline
\end{tabular}


In the present gage made for trial, some frictions and relaxations were unavoidable in its magnification and transmission mechanism, resulting in hysteresis of some $2 \mathrm{~mm}$ on the recorder reading. Fig. 10 shows the hysteresis for the whole mechanism, and Table 1 for the strain-meter alone.

The equivalent water amount $\rho h \mathrm{~mm}$ is deduced from the reading of the recorder $x \mathrm{~mm}$ as

$$
\rho h=\frac{35.7}{A \eta}\left(x_{-2}^{+0}\right) \fallingdotseq 7.3\left(x_{-2}^{+0}\right),
$$

where $A$ is in $\mathrm{m}^{2}$ and \pm the correction for hysteresis, + is for the stage of increasing snow cover amount and - decreasing.

The gage was set in the campus of Hokkaido University, Sapporo, northern Japan, during the winter 1957 through 1958, and a serial field test was carried out. For comparison, snow sampling was frequently made beside the gage with a snow sampler in the same period. The sampler is one designed by $\mathrm{Mr}$. Inoue (Sapporo Meteorological Observatory) using an extrathin wall duralumin pipe for getting better catch, the size being $94 \mathrm{~mm}$ in diameter and $500 \mathrm{~mm}$ in length (Fig. 11). The measurement was made by him with special care. The

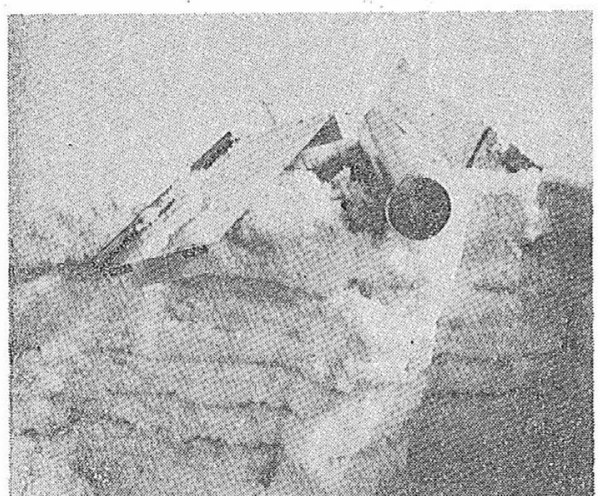

Fig. 11. The snow sampler used for comparison measurement.

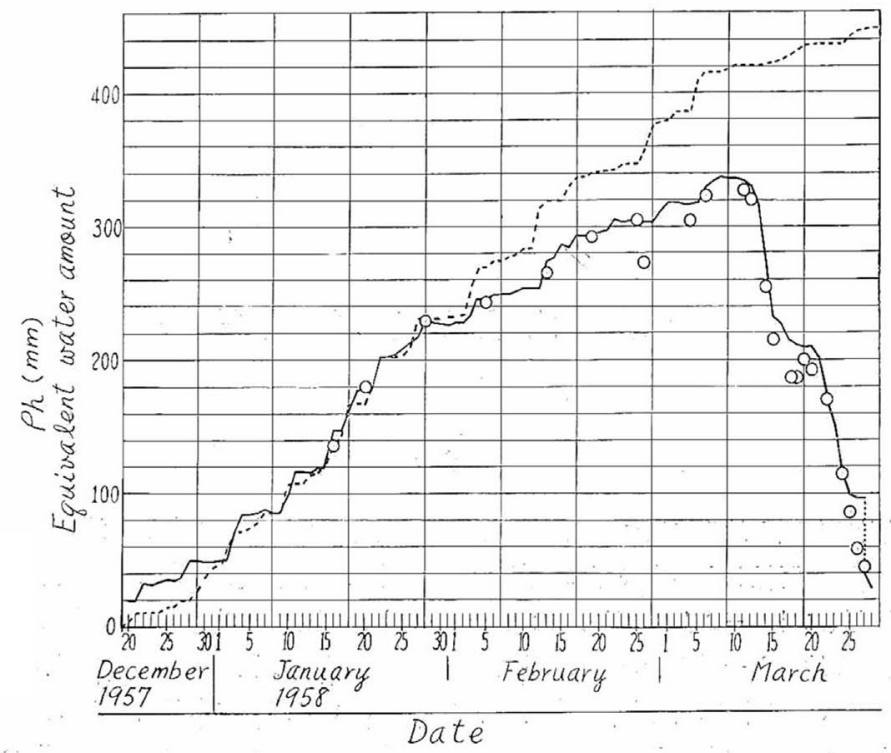

- The present snowgage, measured at Hokkaido University. Snow sampler, measured be side the present gage.

..... The conventional JMA-type snowgage, the integration, measured at Sapporo Met. Obs.

Fig. 12. The observations made in winter 1957 through 1958 at Sapporo. 
observed data are shown in Fig. 12, whose ordinate gives the equivalent water amount converted from the reading on the recorder chart, and the marks $\bigcirc$ show the values measured with the sampler. Both measurements show very good coincidence, except that there exist some discrepancies in the period in which the snow melted. The discrepancies are considered due to the fact that the state of covering snow might be different according to the location of measurement, and also that some melted water might be included in the present snowgage measurement being contained in the covering soil, while none of it be in the sampler. From the standpoint of water resources, the latter could be considered as a merit of the present snowgage and not a fault.

The hysteresis in the present gage stated above made for trial would be its fatal shortcoming. It would be eliminated by improving the link mechanism, and then the gage could be quite satisfactory for practical use. A second model with rod-arm links instead of the present sector gear and rotating rod is now being designed, which would have less friction and better accuracy.

A comparison of the present type snowgage with the one by the radioactive ray method would be interesting, and we are planning to do it in the near future.

Acknowledgements - The authors wish to express their deep thanks to $\mathrm{Mr}$. Mizuno, chief of Weather Instrument Laboratory of Meteorological Research Institute, Mr. Inoue, chief of Weather Instrument Section of Sapporo District Meteorological Observatory, and Professor Yoshida and Assistant Professor Oura, Low Temperature Science Laboratory, Hokkaido. University, for their kind guidance and cooperation throughout this work, and also to Mr. Tsukamoto, M. R. I., for his kind advice.

\title{
重 量 式自記 積 雪 量 計
}

\author{
田村昌進, 津田直吉
}

この積雪量計は積雪を地面飞積つたままの状態で計量自記するものである。地面と直径 $4 \mathrm{~m}$ の底の平 な孔を堀り，この孔の周縁物よび中央部基礎を作り，中央の基礎上飞環状の歪計を㯰き，周囲の基礎上 から雨訃上飞放射状飞「ビーム」を渡し，この「ビーム」を根太としてその上に環状に床を張り，その上 飞土を覆つて周团の地面と一致させる。この場合その床上飞積つた積雪の全重量の $1 / 3$ が中心の歪計飞か かることになるので,この中心の移動量を桩大し中心から $4 \mathrm{~m}$ の距離炕ある自記器飞記録させるのである。 北大低温科学研究所の權内飞設置して試験した結果自記紙から読取つた値はとの時「サンプリング」とよ って得它值とまとえど一致して居り積雪量钼測と実用することもできると思われる。 